\title{
ANALÝZA PREVÁDZKY KOMBINOVANEJ SÚSTAVY
}

\author{
ANALYSIS OF COMBINED SYSTEM'S OPERATION
}

Ing. Zuzana Straková, PhD.

\begin{abstract}
ABSTRAKT
Tvorba vnútorného prostredia $\mathrm{v}$ pracovnej oblasti človeka v priemyselných halových objektoch by mala byt' založená na úzkej spolupráci profesií vykurovania spolu s vetraním a klimatizáciou. Prax však dokazuje, že tomu tak v mnohých prípadoch nie je. Obidve tieto profesie sú vel’a krát riešené samostatne, výsledkom čoho je ich nespolupráca vedúca až k vzájomnému prekážaniu si, či už z hl'adiska dispozičného umiestnenia alebo funkčného prevádzkovania navrhnutých sústav. Vytvorenie vykurovacej a vetracej sústavy, ktorá by jednak bola naprojektovaná v súlade s platnou legislatívou a jednak by vytvárala optimálne vnútorné životné prostredie pre človeka $\mathrm{v}$ jeho pracovnej oblasti a súčasne pri hospodárnej prevádzke, nachádza riešenie v kombinácii hygienického vetrania so sálavým vykurovaním, s použitím rekuperačnej vzduchotechnickej jednotky.
\end{abstract}

Klíčová slova: hygienické vetranie, sálavé vykurovanie, rekuperačná jednotka

\section{ABSTRACT}

The creating of indoor environment in the work area of man in industrial hall buildings should be based on close cooperation between two professions - heating and ventilation and air conditioning. However, practice shows that this is not the truth in many cases. Both professions are many times designed separately. Result is their non-cooperation leading to a mutual obstruction in terms of disposal location or functional operation of the proposed systems. Creating a heating and ventilation system, which would both be designed in accordance with applicable legislation and, secondly, would create an optimal indoor environment for people in working area and at the same time efficient operation, to find solution in combination of radiant heating with hygienic ventilation air recovery air handling unit.

Key words: hygienic ventilation, radiant heating, heat recovery unit

\section{1 ÚVOD}

V projektovej činnosti každý návrh vzduchotechnickej alebo vykurovacej sústavy vychádza z vel'kého množstva predpokladov, ktorých pravdivost' je podložená bud' teoreticky literatúrou alebo konkrétnymi poznatkami z praxe. Sú však prípady, ktoré majú ojedinelé vstupné údaje, alebo pri ktorých sa aplikuje systém vetrania, klimatizácie alebo vykurovania, ktorý je zatial' svojim spôsobom niečím novým, ešte neovereným. Vel’a krát sa v takýchto prípadoch stáva, že ich zrealizovaním sa nedosiahnu projektantom vypočítané, resp. predpokladané parametre vnútorného prostredia. Všetky d'alšie úpravy a opravy bohužial' už len predstavujú navýšené investičné náklady oproti pôvodným [1]. Počitačová analýza na zadefinovanom modeli halového objektu predstavuje pri riešení tohto problému vel'ký prínos. Vd’aka nej možno overit', či navrhovaná sústava prinesie alebo neprinesie očakávaný efekt vo vytvorení tepelnej pohody človeka v jeho pracovnej oblasti a či vytvorenie tohto „komfortu pre človeka“" nebude na úkor príliš vysokej spotreby energie [3]. 


\section{PRINCÍP SPOLUPRÁCE DVOCH SÚSTAV}

Sálavá vykurovacia sústava je navrhnutá na krytie tepelných strát v zimnom období. Zavesené sálavé panely dodávajú tepelnú energiu vykurovanému priestoru prevažne sálaním (70 \%). Sálavá zložka zohrieva stavebné konštrukcie tvoriace vnútorný priestor, t. j. steny a podlahu, od ktorých sa následne ohrieva vnútorný vzduch $\mathrm{v}$ pracovnej oblasti človeka. Konvekčná zložka odovzdaná tepelným výkonom sálavých panelov (30 \%) stúpa konvekciou (prúdením) smerom nahor do podstrešného priestoru haly, kde sa stráca $\mathrm{v}$ podobe tepelných strát strešnou konštrukciou. A práve toto stratové teplo možno využit' v rekuperačnej vzduchotechnickej jednotke na ohrev (resp. predohrev) čerstvého, ale chladného vonkajšieho vzduchu určeného na hygienické vetranie halového objektu. Pre hygienické vetranie je vhodný princíp vertikálneho prívodu vzduchu cez vel'koplošné výustky, ktoré sú vhodným distribučným prvkom z dôvodu ich značnej dížky dosahu prúdu vzduchu. Nahromadenú tepelnú kapacitu vzduchu z neutrálnej zóny a zóny energetickej náročnosti objektu využíva rekuperačná jednotka nasávaním teplého vzduchu z priestoru pod strechou prostredníctvom nasávacích prvkov (napr. jednoradová obdlížniková výustka) [2], [5].

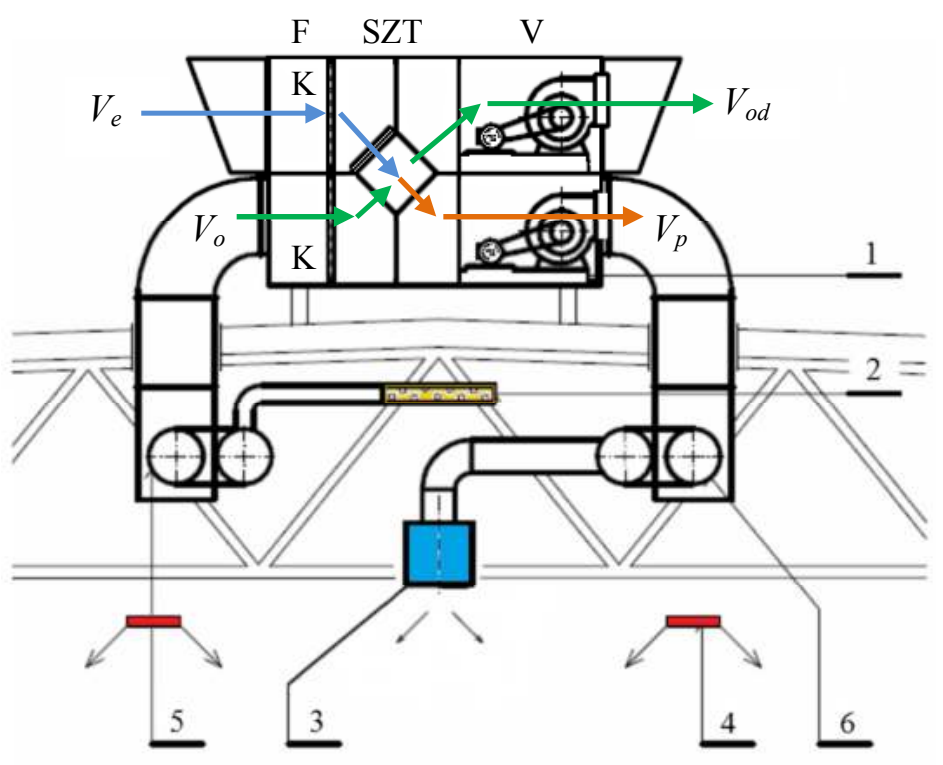

Obr. 1: Vetracia rekuperačná jednotka s centrálnym rozvodom vzduchu velkoobjemovými výustkami

1 - rekuperačná jednotka, 2 - obdížniková jednoradová výustka (odvod vzduchu), 3 - vel'koobjemová výustka (prívod vzduchu), 4 - zavesený sálavý panel, 5 - vzduchovod pre odvádzaný vzduch, 6 - vzduchovod pre privádzaný vzduch, $V_{e}$ - prietok vonkajšieho vzduchu, $V_{p}$ - prietok privádzaného vzduchu, $V_{o}-$ prietok odvádzaného vzduchu, $V_{o d}$ - prietok odpadového vzduchu, K - klapka, F - filter, SZT - spätný zisk tepla $\mathrm{v}$ rekuperačnom výmenníku tepla, $\mathrm{V}$ - ventilátor

Následne ho privádza zberným vzduchovodom do doskového výmenníka v rekuperačnej jednotke, kde vzduch odovzdá svoju tepelnú energiu nasávanému chladnejšiemu vonkajšiemu vzduchu, ktorý sa v závislosti na účinnosti rekuperačného výmenníka zohreje na prijatel'nú teplotu. Ako už bolo uvedené, tento vzduch je vyfukovaný vel'koobjemovými výustkami do priestoru pod zavesenými sálavými panelmi. $\mathrm{V}$ tomto priestore dochádza $\mathrm{k}$ zmiešaniu $\mathrm{s}$ ešte teplejším vnútorným vzduchom a takto upravený vzduch potom pomaly klesá do zóny pracovnej oblasti človeka, kde dosahuje požadovanú vnútornú výpočtovú teplotu. Tepelnú energiu potrebnú pre dohrev vonkajšieho vzduchu z teploty za rekuperačným výmenníkom na vnútornú výpočtovú teplotu vzduchu je potrebné dodat' do vykurovaného priestoru zvýšeným tepelným výkonom sálavých panelov. 


\section{MODEL HALOVÉHO OBJEKTU SKLADOVÉHO CHARAKTERU}

Príklad výpočtu a návrhu sústav v kombinácii hygienického vetrania so sálavým vykurovaním je aplikovaný na stavbe 1-podlažného 1-lodného samostatne stojaceho halového objektu so sociálnoadministratívnym prístavkom situovaným v čele objektu. Ide o skladový charakter prevádzky s častým príjmom a výdajom tovaru. Objekt situovaný do mesta Bratislava (140 m n. m.) patrí z hl'adiska typu územia do 1 . teplotnej oblasti v zimnom období $\left(\theta_{e}=-11^{\circ} \mathrm{C}\right)$, 2. veternej oblasti s rýchlost'ou vetra $\mathrm{v}$ rozmedzí 2 až $5 \mathrm{~m} / \mathrm{s}$ a do A. teplotnej oblasti v letnom období $\left(\theta_{e, m}=20,5^{\circ} \mathrm{C}\right)$.

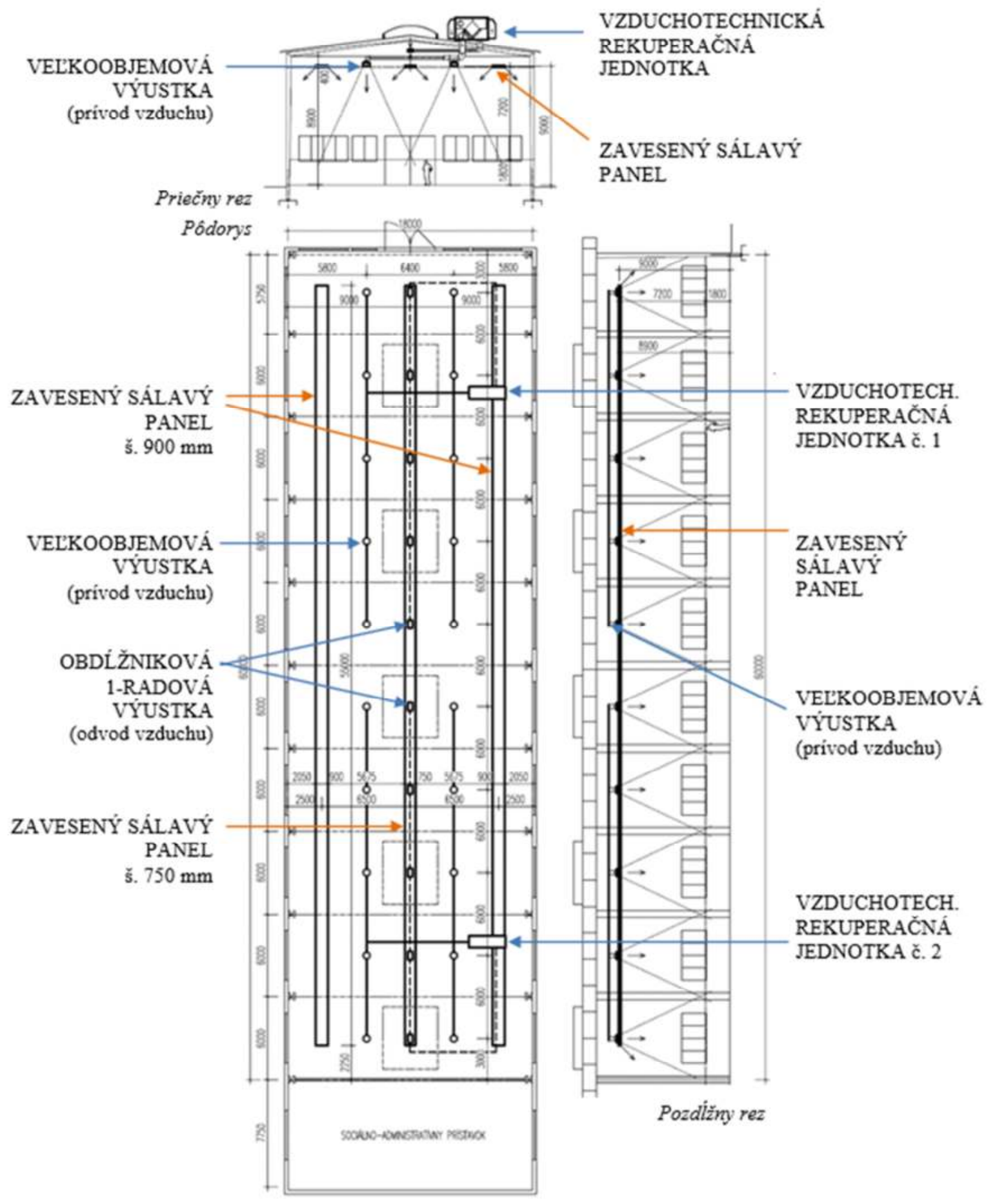

Obr. 2: Pôdorys, priečny a pozdížny rez halového objektu so zakreslením kombinovanej sústavy 


\subsection{Definovanie parametrov vonkajšieho prostredia}

Pri výpočte tepelných ziskov sa v zmysle STN 73 0548:1985 počíta s teplotou vonkajšieho vzduchu $\theta_{e}=30^{\circ} \mathrm{C}$, no pri výpočte hodnoty tepelného zisku z prívodu vonkajšieho vzduchu je výhodnejšie uvažovat' s vyššou teplotou $\theta_{e}=35{ }^{\circ} \mathrm{C}$ z dôvodu, aby aj v extrémne teplých letných dňoch bola regulácia vzduchotechnickej jednotky schopná zabezpečit' požadovanú teplotu vnútorného vzduchu $\theta_{i}=26{ }^{\circ} \mathrm{C}$, aj ked' legislatíva dovoluje pri maximálnych teplotách vonkajšieho vzduchu v letnom i zimnom období znížit' prívod vonkajšieho vzduchu krátkodobo na polovičnú hodnotu [6].

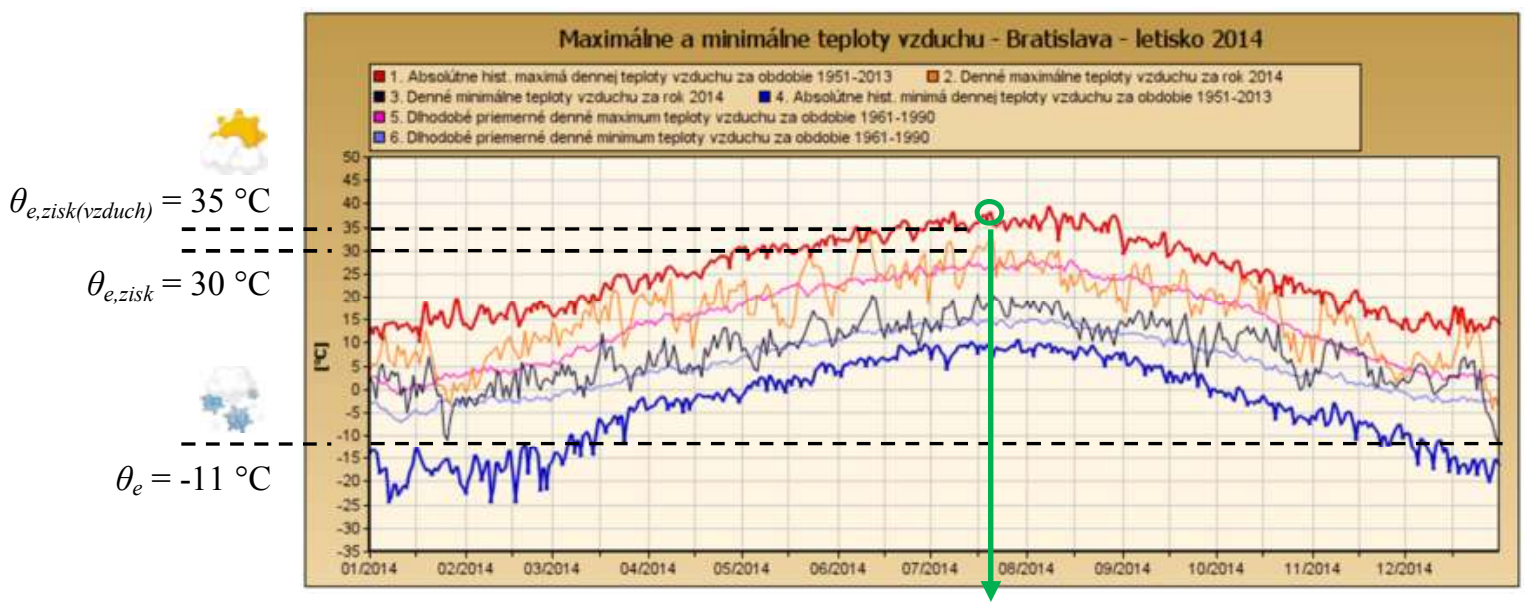

DEŇ VÝPOČTU TEPELNEJ ZÁŤAŽE: 21. júl (Slovensko)

Obr. 3: Maximálne a minimálne teploty vonkajšieho vzduchu

Zmenou intenzity slnečnej radiácie sa mení ako intenzita difúznej slnečnej radiácie, tak aj teplota vonkajšieho vzduchu $\theta_{e}$ (tab. 1).

\begin{tabular}{|l|c|c|c|c|c|c|c|c|c|c|c|c|}
\hline Mesiac & I. & II. & III. & IV. & V. & VI. & VII. & VIII. & IX. & X. & XI. & XII. \\
\hline Teplota $\theta_{e}$ & -11 & -5 & +10 & +15 & +20 & +25 & +30 & +27 & +20 & +10 & 0 & -8 \\
\hline
\end{tabular}

Tab. 1: Priemerné teploty vonkajšieho vzduchu $\theta_{e}\left({ }^{\circ} \mathrm{C}\right) \mathrm{v}$ jednotlivých mesiacoch [7]

\subsection{Definovanie parametrov vnútorného prostredia}

Z hl'adiska analýzy prevádzky kombinovanej sústavy sú dôležité teplota vnútorného vzduchu $\theta_{i}$ a relativna vlhkost' vnútorného vzduchu $\varphi_{i}$. Záväzný predpis sa zmieňuje o maximálnych hodnotách pre letné ročné obdobie $\left(\theta_{i}=26^{\circ} \mathrm{C}\right)$ a minimálnych hodnotách pre zimné ročné obdobie $\left(\theta_{i}=18{ }^{\circ} \mathrm{C}\right)$.

\begin{tabular}{|l|c|c|c|c|c|c|c|c|c|c|c|c|}
\hline Mesiac & I. & II. & III. & IV. & V. & VI. & VII. & VIII. & IX. & X. & XI. & XII. \\
\hline Teplota $\theta_{i}$ & 18 & 18 & \multicolumn{1}{|c|}{$18 \rightarrow 26$} & 26 & 26 & 26 & $26 \rightarrow 18$ & 18 \\
\hline Vlhkost' $\varphi_{i}$ & \multicolumn{10}{|c}{30 až 70} \\
\hline
\end{tabular}

Tab. 2: Teplota vnútorného vzduchu $\theta_{i}\left({ }^{\circ} \mathrm{C}\right)$ a relatívna vlhkost' vnútorného vzduchu $\varphi_{i}(\%)$ 


\section{PREHLAD ENERGETICKÝCH BILANCIÍ V JEDNOTLIVÝCH MESIACOCH}

Energetická bilancia vo všeobecnosti vyjadruje pomer medzi príjmom a výdajom energie. $Z$ hl'adiska

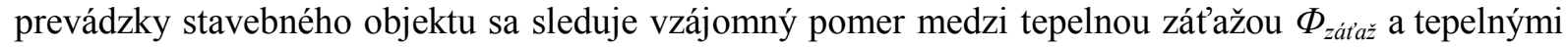
stratami $\Phi_{\text {straty. }}$ Svoje maximá dosahujú počas letnej a zimnej prevádzky, no v opačnom pomer, t. j. počas letnej prevádzky je zátaž maximálna a straty minimálne až nulové; počas zimnej prevádzky je tomu naopak. V prechodných ročných obdobiach (jar, jeseň) sa tieto dve hodnoty k sebe približujú. Pri meniacej sa teplote vonkajšieho vzduchu sa požadovaná teplota vnútorného vzduchu dá dosiahnut' len pri dodaní vyrobenej energie v podobe tepla a chladu. Pokial' sa množstvo energie spotrebovanej rovná množstvu energie dodanej, potom je energetická bilancia vyvážená [1], [4]. Postupne pre jednotlivé mesiace boli dosadením zadefinovaných parametrov vonkajšieho a vnútorného prostredia vypočítané vstupné hodnoty pre výpočet celkovej energetickej bilancie, ktorých výsledky sú uvedené v nasledujúcej tabul'ke:

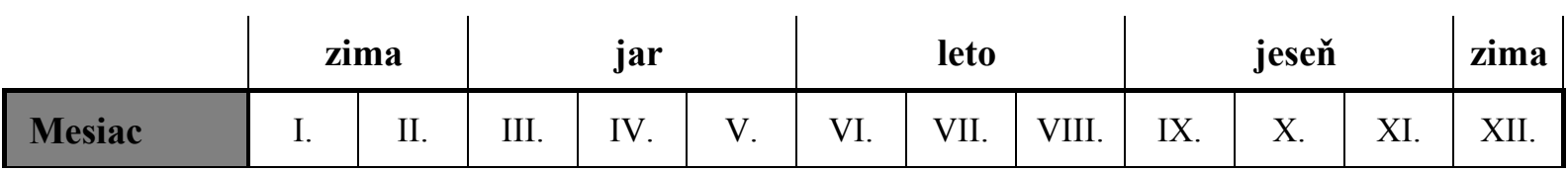

Vypočítané hodnoty energetickej bilancie

\begin{tabular}{|l|c|c|c|c|c|c|c|c|c|c|c|c|}
\hline $\begin{array}{l}\text { Tepelné zisky } \\
\Phi_{\text {zisky }}(\mathrm{W})\end{array}$ & 0 & 0 & 34050 & 38417 & 40842 & 38460 & 38630 & 36403 & 34467 & 29336 & 0 & 0 \\
\hline $\begin{array}{l}\text { Tepelný zisk } \\
\text { (vonk. vzduch) } \\
\Phi_{e, z i s k}(\mathrm{~W})\end{array}$ & 0 & 0 & 0 & 0 & 0 & 0 & 43414 & 40953 & 0 & 0 & 0 & 0 \\
\hline $\begin{array}{l}\text { Tepelná zát’až } \\
\Phi_{z \text { átaż }}(\mathrm{W})\end{array}$ & 0 & 0 & 34050 & 38417 & 40842 & 38460 & 82044 & 77356 & 34467 & 29336 & 0 & 0 \\
\hline
\end{tabular}

Dodaná tepelná energia_Vykurovacia sústava (zavesené sálavé panely)

\begin{tabular}{|l|l|l|l|l|l|l|l|l|l|l|l|l|}
\hline $\begin{array}{l}\text { Tepelný výkon } \\
\Phi_{z s p}(\mathrm{~W})\end{array}$ & 86326 & 62404 & 28321 & 14424 & 0 & 0 & 0 & 0 & 0 & 28321 & 51043 & 73523 \\
\hline
\end{tabular}

Dodaná tepelná a chladiaca energia_Vzduchotechnická sústava (vetracia rekuperačná jednotka)

\begin{tabular}{|l|c|c|c|c|c|c|c|c|c|c|c|c|}
\hline $\begin{array}{l}\text { Teplota vzduchu } \\
\text { (tepelný vankús }) \\
\theta_{i, t v}\left({ }^{\circ} \mathrm{C}\right)\end{array}$ & 19,50 & 20,24 & 21,16 & 21,53 & 20 & 25 & 26 & 26 & 20 & 21,16 & 21,92 & 19,45 \\
\hline $\begin{array}{l}\text { Teplota vzduchu } \\
\text { (za rekuperátorom) } \\
\theta_{i, \text { rek }}\left({ }^{\circ} \mathrm{C}\right)\end{array}$ & 17 & 18 & 19 & 20 & 20 & 28 & 28 & 28 & 20 & 19 & 19 & 18 \\
\hline $\begin{array}{l}\text { Účinnost } \\
\text { rekuperátora } \\
\eta_{s z t}(\%)\end{array}$ & 93 & 90 & 76 & 75 & 75 & 75 & 75 & 76 & 76 & 78 & 88 & 91 \\
$\begin{array}{l}\text { Tepelný výkon } \\
\text { ohrievača } \\
\Phi_{\text {oh }}(\mathrm{W})\end{array}$ & 600 & 200 & - & - & - & - & - & - & - & - & - & 600 \\
\hline $\begin{array}{l}\text { Chladiaci výkon } \\
\text { chladiča } \\
\Phi_{c h}(\mathrm{~W})\end{array}$ & - & - & - & - & 41012 & 42760 & 83580 & 78360 & 35704 & - & - & - \\
\hline
\end{tabular}

Tab. 3: Prehl’ad výsledkov energetickej bilancie

Z uvedenej tabul'ky vyplýva, že vplyvom meniacej sa klímy vonkajšieho prostredia hodnoty tepelných strát a tepelnej zát'aže vo vnútornom priestore halového objektu počas roka sú dost' rozdielne. 


\section{ANALÝZA PREVÁDZKY KOMBINOVANEJ SÚSTAVY}

Ciel’om analýzy prevádzky kombinovanej sústavy je zistit', ako sa ich vzájomná spolupráca prejaví na potrebe tepelnej a chladiacej energie v porovnaní so situáciou, kedy by $\mathrm{v}$ halovom objekte fungovali dve samostatne pracujúce sústavy (vetranie priamovýhrevnými teplovzdušnými jednotkami + vykurovanie sálavými panelmi).

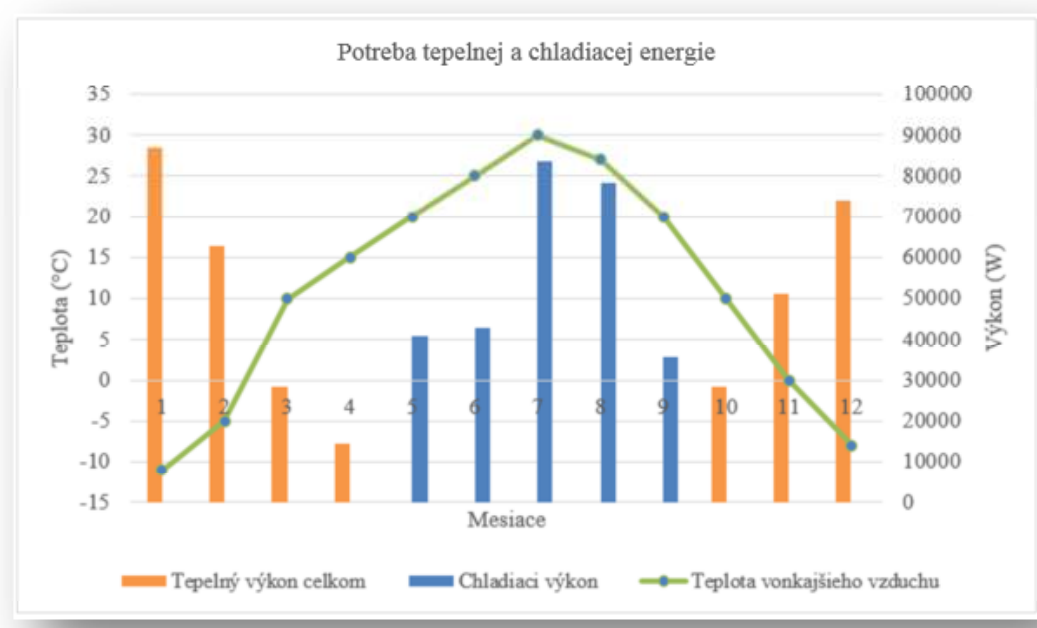

Obr. 4: Závislost' potreby tepla a chladu na teplote vonkajšieho vzduchu (kombinovaná sústava)

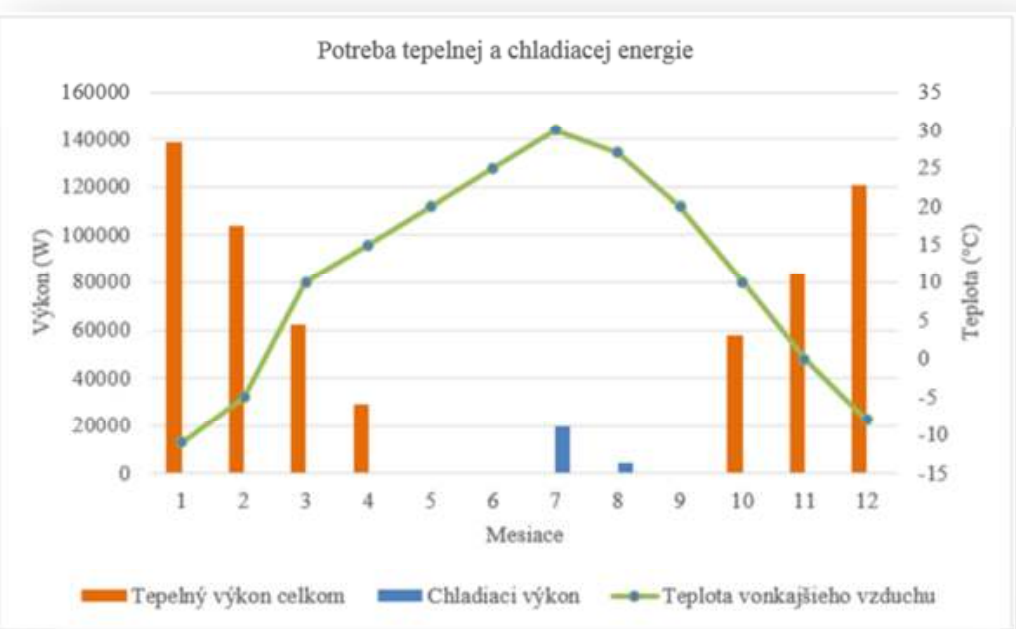

Obr. 5: Závislost' potreby tepla a chladu na teplote vonkajšieho vzduchu (samostatné dve sústavy)

$\mathrm{Na}$ základe grafických výstupov analýzy je možno konštatovat', že čísla hovoria jednoznačne v prospech kombinovanej sústavy. Svojou funkciou a vzájomnou spoluprácou dosahuje oproti vetracej sústave s priamym vetraním značných energetických úspor a zároveň pri plnení požiadaviek kladených na vnútorné pracovné prostredie. 


\section{POUŽITÁ LITERATÚRA}

[1] KOTRBATÝ, M. - HOJER, O. - KOVÁŘOVÁ, Z. Hospodařeni teplem v prưmyslu. Nejlevnějši energie je energie ušetřena. Praha : ČSTZ, 2009. 266 s. ISBN 978-80-86028-41-5.

[2] PETRÁS̆, D. a kol. Vykurovanie vel'kopriestorových a halových objektov. Bratislava : Jaga, 2007. 215 s. ISBN 978-80-8076-047-2.

[3] KABELE, K. - HOJER, O. - KOTRBATÝ, M. - SOMMER, K. - PETRÁŠ, D. Energy efficient heating and ventilation of large halls. The REHVA guidebook No. 15. Bruxelles : REHVA, 2011. 78 s. ISBN 978-2-930521-06-0.

[4] KOUDELKOVÁ, D. Regulace větrání podle kvality vnitřního vzduchu. In TZB Haustechnik. ISSN 1803-4802, 2011, roč. 4, č. 1, s. 46-49.

[5] BAŠTA, J. - DRKAL, F. - KOTRBATÝ, M. Vytápění - sálavé a teplovzdušné vytápění průmyslových a občanských staveb. Praha: STP, 1998. 220 s. ISBN 80-02-01240-2.

[6] Nariadenie vlády SR č. 391/2006 Z. z. o minimálnych bezpečnostných a zdravotných požiadavkách na pracovisko.

[7] https/www.shmu.sk 